The University of Akron

\title{
IdeaExchange@UAkron
}

Proceedings from the Document Academy

University of Akron Press Managed

December 2016

\section{From Fief to Clan: Boisot's Information Space Model as a Documentary Theory for Cultural and Institutional Analysis}

Lin Wang

School of Information, University of California, Berkeley, wanglinpku@163.com

Michael Buckland

School of Information, University of California, Berkeley, buckland@ischool.berkeley.edu

Please take a moment to share how this work helps you through this survey. Your feedback will be important as we plan further development of our repository.

Follow this and additional works at: https://ideaexchange.uakron.edu/docam

Part of the Library and Information Science Commons, and the Models and Methods Commons

\section{Recommended Citation}

Wang, Lin and Buckland, Michael (2016) "From Fief to Clan: Boisot's Information Space Model as a Documentary Theory for Cultural and Institutional Analysis," Proceedings from the Document Academy: Vol. 3 : Iss. 2 , Article 10. DOI: https://doi.org/10.35492/docam/3/2/10

Available at: https://ideaexchange.uakron.edu/docam/vol3/iss2/10

This Conference Proceeding is brought to you for free and open access by University of Akron Press Managed at IdeaExchange@UAkron, the institutional repository of The University of Akron in Akron, Ohio, USA. It has been accepted for inclusion in Proceedings from the Document Academy by an authorized administrator of

IdeaExchange@UAkron.For more information, please contact mjon@uakron.edu, uapress@uakron.edu. 


\section{Introduction}

When the documentation movement emerged at the beginning of 20th century, it had a universal perspective. The founder of European documentation, Belgian documentalist Paul Otlet, for example, believed strongly in international peace and social progress through standards, international collaboration, and open access (Buckland, 2007). An idealist, he thought documentary practices would lead to world peace and progress. The broad view of documentation largely ignored cultural, economic, and political factors associated with rivalry, competition, and cultural differences. In this paper we explore the relationships between these divergent influences and documentary practices through examination of the "Information Space" ("I-Space") model of Max Boisot (1943-2011).

\section{Max Boisot (1943-2011)}

Max Henri Boisot was born in 1943 and educated in the United Kingdom and the United States. He studied architecture at the University of Cambridge and city planning at the Massachusetts Institute of Technology. After being a general manager and consultant for eight years, he began to teach at the Institut Européen d'Administration des Affaires (INSEAD), the well-known business school in France. The Euro-Asia center at INSEAD provided him an opportunity to collect data about technology transfer in Asian countries, which stimulated his initial work on his Information Space (I-Space) model.

In his doctoral dissertation at Imperial College, London, 1982, he developed a Cultural Space (C-Space) model, the original version of his I-Space model. Two years later, he was appointed as dean and director of the China-European Economic Community (EEC) Management Programme, the first western MBA program in the Peoples Republic of China. During this appointment there, from 1984 to 1989, he devoted himself to Chinese management education and many Chinese MBA students of this program in the 1980s are now CEOs or general managers in large Chinese companies and others are deans or distinguished professors in top Chinese top business schools. The program evolved into the China-Europe International Business School (CEIBS), ranked 17th in the Financial Times Global MBA Rankings in 2016.

After leaving China, Boisot held appointments as professor or senior research 
fellow at several different universities in different countries, including the ESADE Business School in Spain; as Chair of Strategic Management at the University of Birmingham, England; the University of Oxford; the Wharton Business School of the University of Pennsylvania; and Hong Kong University. He was an independent scholar who chose not to be permanently on the faculty of any university and who enjoyed being an academic traveler around the world (Ihrig and Child, 2013). Boisot's unorthodox academic career life and transitions between East and West seem to have facilitated his original ideas about information flow, particularly in relation to cultures and institutions.

\section{The Information Space Model}

Boisot believed that the structuring and communication of information oriented human learning, social behavior, and organizational systems and also provided the foundation for value creation and for the utilization of knowledge assets (Child, Ihrig and Merali, 2014). These conceptions formed the foundation of his Information-Space (I-Space) model which he elaborated and applied throughout his academic life.

The I-Space model provides a framework for studying information sharing within a given population of agents. The primary dimensions of this framework are: codification, abstraction, and diffusion of information. Boisot's model enables exploration of human information flow and learning behavior, culture, and institutional structures (Boisot, 1995, 1998; Boisot, MacMillan and Han, 2008). The model is shown in Figure 1.

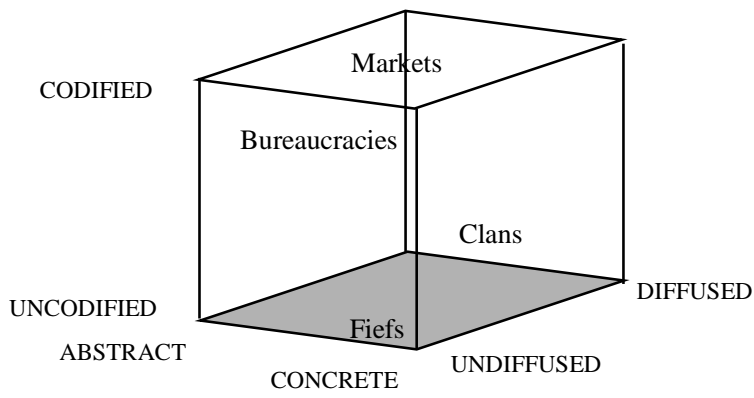

Figure 1. Four institutional types in Boisot's I-Space model (adapted from Boisot, 1998, p. 126). 
The three dimensions are defined as follows:

Codification is an agent's activity that assigns the sensory data to explicit perceptual and conceptual categories. Codification is the transformation of information into graphic records (Boisot, 1995). It refers to the degree of formalization of information utilized in transactions. In more familiar terminology, codification corresponds to the continuum from tacit knowledge to explicit, recorded knowledge.

Abstraction is the process that economizes on perceptual and conceptual effort by integrating codified information into the most essential attributes to create the minimum number of categories that are applicable in a context. In information science terms, this corresponds to knowledge organization through categorization, classification and vocabulary control. Boisot (1995) considered abstraction as the construction of Karl Popper's abstract knowledge objects without any particular spatio-temporal form. When applied in physical settings, knowledge has objective substance and subjective aspects, meaning that it is materialized and affects mental states. This process is called impacting and is similar to Oliver Williamson's (1975) concept of "impacting" in neo-institutional economics.

Both codification and abstraction can reduce the transaction costs of information flow and exchange. By taking the acts of codification and abstraction together, an agent is able to save information processing resources and make transactions more economical and extensive (Boisot, 2002). The use here of transaction costs echoes the work of economist Ronald Coase.

Diffusion refers to the information sharing process within a given population. It describes the availability of information within an agent group in a given time frame and context (Boisot, Child and Redding, 2011). Many factors influence the diffusion of information. Information and communication technologies facilitate the speed of information flow and extend its coverage. Government censorship limits the free flow of some kinds of information. Economic factors also have impacts on the accessibility of information resources, as Boisot (1995:424) noted "Political and economic control of diffusion of knowledge [...] affects the social system's ability to evolve epistemologically."

For Boisot, the I-Space model was an analytical tool for cultural and institutional analysis. Although cultures and institutions have been widely studied by scholars, Boisot approached these issues in a unique way: information-based institutional analysis. He explored cultures and institutions in terms of their 
information structures and information environments (Guastello, 1998). People with different cultural backgrounds favor different patterns of codification, abstraction and diffusion, that is, different organizing styles of sense-making. For example, Chinese people like face-to-face interaction when doing business and German business managers think a formalized negotiation procedure and well-codified contract documents are necessary for commerce prosperity. Repeated behavior evolves over time into acceptable cultural and institutional practices which shape behavior within the society in which they operate, thus lowering transaction costs (Redding, 2013; Boisot, 1995; Boisot, Child and Redding, 2011). Preferred modes of social information processing and information environment make the institutional arrangements, and institutions in turn shape and consolidate the information processing behavior and information environment.

Boisot classified institutions into four types within his I-Space model: markets, bureaucracies, clans, and fiefs (Boisot, 1995, 1998; Child, 2013):

- Bureaucracies: Economic transactions are based on codified (explicit, recorded) and abstract (organized) information and diffusion is limited and under central control

- Markets: Economic transactions are based on codified (explicit) and abstract (standardized) information that is widely accessible to all agents in the market

- Fiefs: Economic transactions are highly personal and rely on uncodified (implicit), concrete (particular), undiffused (private) information that is usually owned (controlled) by charismatic leaders and few other key players

- Clans: Economic transactions are based uncodified (implicit) and concrete (particular) information that is diffused only within a small community

Boisot consistently used the word "information," but if we accept the division of uses of the word "information" into the three categories of information-as-knowledge, information-as-process, and information-as-thing, and equate the latter with "document" (Buckland 1991; 1997), then we can regard Boisot's Information Space model as a document-based model. Information Space is essentially a document space in which codification, abstraction, and diffusion of documents constitute three dimensions of a document-based model. This 
means there exist different document configurations (forms, genres, diffusion) that fundamentally influence the evolution of institutions and choice of transactional arrangement. Once institutions and transactional arrangements are formed, they will in turn consolidate the documentary infrastructure and documentary behavior pattern. In this sense, Boisot's I-Space is a documentary theory for cultural and institutional analysis.

In Table 1, we restate the documentary and organizational features of I-Space by positioning the four types onto the three dimensions of codification, abstraction, and diffusion.

\begin{tabular}{|c|c|}
\hline $\begin{array}{l}\text { Bureaucracies } \\
\text { - Documents diffusion limited and under central } \\
\text { control. } \\
\text { - Documents are codified and abstract. } \\
\text { - Relationships impersonal and hierarchical. } \\
\text { - Submission to superordinate goals. } \\
\text { - No necessity to share values and beliefs. }\end{array}$ & $\begin{array}{l}\text { Markets } \\
\text { - Documents widely diffused, no control. } \\
\text { - Documents are codified and abstract. } \\
\text { - Relationships impersonal and competitive. } \\
\text { - No superordinate goals. } \\
\text { - Horizontal coordination through } \\
\text { self-regulation. } \\
\text { - No necessity to share values and beliefs. }\end{array}$ \\
\hline $\begin{array}{l}\text { Fiefs } \\
\text { - Documents diffusion limited by lack of } \\
\text { codification to face-to-face relationship. } \\
\text { - Documents are uncodified and concrete. } \\
\text { - Relationships personal and hierarchical } \\
\text { (feudal/charismatic). } \\
\text { - Submission to superordinate goals. } \\
\text { - Hierarchical coordination. } \\
\text { - Necessity to share values and beliefs. }\end{array}$ & $\begin{array}{l}\text { Clans } \\
\text { - Documents are diffused but still limited by } \\
\text { lack of codification to face-to-face } \\
\text { relationships. } \\
\text { - Documents are uncodified and concrete. } \\
\text { - Relationships personal nonhierarchical. } \\
\text { - Goals are shared through a process of } \\
\text { negotiation. } \\
\text { - Horizontal coordination through } \\
\text { negotiation. } \\
\text { - Necessity to share values and beliefs. }\end{array}$ \\
\hline
\end{tabular}

Table 1. Four Institutional Types. Based on Boisot (1998, 127) 


\section{Case Study: Chinese Economic Reform}

As one of the first Western scholars to study Chinese economic reform, Boisot applied his I-Space framework to making sense of the Chinese economy and derived valuable insights into China's distinctive and complex economic institutions (Child, 2013; Child, Ihrig and Merali, 2014). We can use Chinese economic reform as a case study to illuminate Boisot's contribution.

Boisot and Child (1988) investigated China's urban reforms in the 1980s and pointed out the bureaucratic failure. For bureaucratic institutions, documents should be explicitly codified and abstracted. Document flow is strictly regulated by the operation of a hierarchy, and a rational legal system guarantees the formalized authority of documents. There is strong control from the top of a hierarchy. The impersonal procedures and uniform administrative system guide behavior. But unlike some European countries, China had no traditional heritage of a well-codified, formalized, authoritative documentary infrastructure before the introduction of Marxism. In the 1980s, China had a codified documentary system that was copied from the Soviet Union, but it was more a ritual than a substantial system (Boisot and Child, 1996).

In fact, Chinese bureaucracies were ineffective. The document practice in China was unstructured (oral, face-to-face) because the Chinese have a long traditional cultural preference for relatively uncodified relationships and transactions. The flow of physical documents is small and the distribution of documents is skewed by the interests of a few opportunistic players (Child, Ihrig \& Merali, 2014; Boisot and Child, 1988). Such a document configuration gave rise to fief-like transactional arrangements. In Boisot's view, Chinese city and local authorities dominated enterprises within their jurisdiction in a fief style at that time. They exchanged preferential treatment and protection from outside competitors for the loyalty of vassal firms; power relationships between superior and subordinate organization were personalized; and city and local authorities hoarded documents so that they could control enterprise behavior. In such a context, the key managerial skill is to "engage in a linked network of hierarchical face-to-face relationships in which personal power is traded, using loyalty, compliance, and protection as the medium of exchange", which is the logic of fiefs (Boisot and Child, 1988). The legal and documentary infrastructures that could take China beyond fiefs still needed to be implemented. Boisot and Child $(1988,521-522)$ termed it the "Iron law of fiefs". 
In the 1990s, the situation changed greatly in China. A clan-like economic pattern emerged due to decentralization of the state administrative power. In a clan institution, documents are uncodified and concrete; they are diffused but the degree of diffusion is limited owing to their unstructured form; documents circulate within a small community network with close internal connections. Since relationships are non-hierarchical and collaboration is horizontal, small document communication networks are formed. This documentary infrastructure constituted a transition from fief structure to a clan structure.

Boisot and Child (1996) observed that given the condition of long-existing Chinese traditional values (Confucianism) and social organization and the lack effective codification and abstraction and the decentralization of power leads not to markets but to clans, permitting a more local and personalized social order. Generally speaking, rights emerged from negotiations between central and local authorities, communities, and private interests. Boisot and Child concluded that the Chinese economic order was the combination of limited document structuring and flow and "communal property rights and organization of economic transactions." They called this distinctive institutional form "network capitalism" (Boisot and Child, 1996:600, 622).

By network capitalism they meant crony capitalism not capitalism based on telecommunications networks, although improved telecommunication facilitates evolution toward clans. Basic features of this network capitalism according to Boisot and Child (1996; 1999) are:

- A relatively uncodified and concrete documentary exchange system in support of transactions.

- Deep social embeddedness;

- An implicit and fluid dynamic of trust-based relationships, known in China as guan $x i$; and

- Complexity and uncertainty are absorbed rather than reduced

Boisot and his colleagues believed network capitalism represents a distinct way towards modernization different from the Western way based on codified, standardized transactional norms. They saw informal, unstructured documentary systems in which corporations, local governments, and interest groups ally closely through guan xi relationships to form transactional networks in which governmental authorities play the dominant roles in network formation and the negotiation of business and property rights. 


\section{Conclusion}

We summarized the documentary and organizational features of four institutional types based on the I-Space model of Max Boisot (1998). The basic idea is that different document configurations (forms, genres, diffusion) fundamentally influence the evolution of institutions and choice of transactional arrangement. Once institutions and transactional arrangements are formed, they will in turn consolidate the documentary infrastructure and documentary behavior pattern. This recalls Suzanne Briet's assertion that documentation is a cultural specialization (Briet 2006, 21; Day 2006).

Max Boisot died in 2011. The I-Space model, as published, could have been more extensively developed. In future work, we plan to augment this model with more attention to content as opposed to form, issues of cognitive authority and trust, and related work in knowledge management, information management, and special librarianship.

\section{References}

Boisot, M. (2002). The Creation and Sharing of Knowledge. In C. W. Choo and N. Bontis (Eds.), The Strategic Management of Intellectual Capital and Organizational Knowledge, (pp. 65-77). Oxford, UK: Oxford University Press.

Boisot, M. (1998). Knowledge Assets: Securing Competitive Advantage in the Information Economy. Oxford, UK: Oxford University Press.

Boisot, M. (1995). Information Space: A Framework for Learning in Organizations, Institutions and Culture. London, UK: Routledge.

Boisot, M., and Child, J. (1988). The Iron Law of Fiefs: Bureaucratic Failure and the Problem of Governance in the Chinese Economic Reforms, Administrative Science Quarterly, 33, 507-527.

Boisot, M., and Child, J. (1996). From Fiefs to Clans and Network Capitalism: Explaining China's Emerging Economic Order. Administrative Science Quarterly, 41(4), 600-628.

Boisot, M., and Child, J. (1999). Organizations as Adaptive Systems in Complex Environments: The Case of China. Organization Science 10(3), 237-252.

Boisot, M., Child, J., and Redding, G. (2011) Working the System: Toward a Theory of Cultural and Institutional Competence. International Studies of Management and Organization, 41(1), 62-95. 
Boisot, M., MacMillan, I., and Han, K. S. (2007). Explorations in Information Space: Knowledge, Actors, and Firms. Oxford, UK: Oxford University Press.

Briet, S. (2006). What is Documentation? Lanham, MD: Scarecrow Press. http://info.slis.indiana.edu/ roday/what\%20is\%20documentation.pdf

Buckland, M. K. (1991) Information as Thing. Journal of the American Society for Information Science, 42(5), 351-360. Available at: http://people.ischool.berkeley.edu/ buckland/thing.html

Buckland, M. K. (1997). What is a "Document"? Journal of the American Society for Information Science, 48(9), 804-809. Available at: http://people.ischool.berkeley.edu/ buckland/whatdoc.html

Buckland, M. K. (2007). On the cultural and intellectual context of European Documentation in early twentieth century. In: W. B. Rayward (Ed.), European Modernism and the Information Society: Informing the Present, Understanding the Past (pp. 44-57). Aldershot, UK: Ashgate.

Child, J. (2013). Analyses of the Chinese System. In J. Child and M. Ihrig, (Eds.) Knowledge, Organization, \& Management - Building on the Work of Max Boisot (pp. 49-60). Oxford, UK: Oxford University Press.

Child, J., Ihrig, I., and Merali, I. (2014). Organization as Information - A Space Odyssey. Organization Studies, 35(6), 801-824.

Day, R. E. (2006). "A necessity for our time": Documentation as "cultural technique" in What is documentation?. In S. Briet, What is Documentation? (pp. 47-63). Lanham, MD: Scarecrow Press. Available at: http://info.slis.indiana.edu/ roday/Briet_commentary.pdf

Guastello, S. J. (1998). Book Review: Information Space by Max H Boisot. Journal of Economic Behavior \& Organization. 33, 303-311.

Ihrig, M., and Child, J. (2013). Max Boisot and the Dynamic Evolution of Knowledge. In J. Child and M. Ihrig (Eds.), Knowledge, Organization, \& Management - Building on the Work of Max Boisot (pp. 3-18). Oxford, UK: Oxford University Press.

Redding, G. (2013). The I-Space as a Key to History and to Culture. In J. Child and M. Ihrig (Eds.), Knowledge, Organization, \& Management - Building on the Work of Max Boisot (pp. 199-204). Oxford, UK: Oxford University Press.

Williamson, O. E. (1985). The Economic Institutions of Capitalism: Firms, Markets, Rational Contracting. New York, NY: The Free Press. 